\title{
PERBEDAAN KEMANDIRIAN ANAK USIA PRA SEKOLAH DITINJAU DARI IBU BEKERJA DAN IBU RUMAH TANGGA DI SEKOLAH ALAM JABALUSSALAM BALIKPAPAN TAHUN AJARAN 2017/2018
}

\author{
Azizatin Nasucha ${ }^{1}$, Tri Astuti Nur'aini ${ }^{2}$, Prita Indriawati ${ }^{3}$ \\ Universitas Balikpapan ${ }^{1}$, Universitas Balikpapan ${ }^{2}$, Universitas Balikpapan ${ }^{3}$ \\ pos-el:Azizahnasucha@gmail.com ${ }^{1}$, tri.astuti@uniba-bpn.ac.id ${ }^{2}$, prita@uniba-bpn.ac.id ${ }^{3}$
}

\begin{abstract}
ABSTRAK
Penelitian ini dilatarbelakangi oleh adanya perbedaan kemandirian anak yang dipengaruhi oleh beberapa faktor salah satunya ialah status kerja ibu. Penelitian ini bertujuan untuk mengetahui perbedaan kemandirian anak usia pra sekolah ditinjau dari ibu bekerja dan ibu rumah tangga di Sekolah Alam Jabalussalam.

Penelitian ini merupakan penelitian kuantitatif jenis komparatif dengan populasi berjumlah sebanyak 148 siswa dan sampel yang diambil sebanyak 52 siswa. Teknik pengumpulan data pada penelitian ini dengan menggunakan skala kemandirian anak usia pra sekolah yang kemudian di analisis dengan menggunakan uji Hipotesis Independent Sample tTest.

Hasil penelitian menunjukan bahwa perolehan nilai $t_{\text {hitung }}>t_{\text {tabel }}(5,085>1,675)$ dengan taraf nilai signifikansi $0,05 \mathrm{p}_{\text {value }}(0,000<0,05)$, maka $\mathrm{H}_{0}$ ditolak dan $\mathrm{H}_{\mathrm{a}}$ diterima, dengan nilai rata-rata yaitu 11,17029 untuk tingkat kemandirian anak usia pra sekolah yang diasuh oleh ibu bekerja dan nilai rata-rata 90,7308 untuk tingkat kemandirian anak usia pra sekolah yang diasuh oleh ibu rumah tangga. Hal ini menunjukkan bahwa hipotesis diterima sehingga dapat disimpulkan bahwa terdapat perbedaan kemandirian anak usia pra sekolah ditinjau dari ibu bekerja dan ibu rumah tangga di Sekolah Alam Jabalussalam Tahun Ajaran 2017/2018.
\end{abstract}

Kata kunci : Ibu bekerja, ibu rumah tangga, kemandirian anak usia pra sekolah

\section{ABSTRACT}

This research is motivated by the existence of differences in children's independence which are influenced by several factors, one of which is the mother's work status. This study aims to determine the differences in the independence of pre-school age children in terms of working mothers and housewives in the Jabalussalam Nature School. This study is a comparative type quantitative research with a population of 148 students and a sample of 52 students. Data collection techniques in this study by using the independence scale of pre-school age children were then analyzed using the Independent Sample t-Test hypothesis.

The results showed that the acquisition of tcount $>$ ttable $(5.085>1.675)$ with a significance level of $0.05 \mathrm{p}$ value $(0.000<0.05)$, then $\mathrm{HO}$ was rejected and Ha was accepted, with an average value of 11.17029 for the level of child independence pre-school age attended by working mothers and an average value of 90,7308 for the level of independence of pre-school age children cared for by housewives. This shows that the hypothesis is accepted so that it can be concluded that there are differences in the independence of pre-school children aged from working mothers and housewives in Jabalussalam Nature School 2017/2018 Academic Year.

Keywords: Mother working, housewife, independence of pre-school age children 


\section{PENDAHULUAN}

Anak mengalami pertumbuhan dan perkembangan yang cukup unik pada masamasa awal hidupnya didunia yaitu ketika anak berusia 0 tahun hingga 6 tahun. Pada masa - masa ini, sering disebut dengan istilah golden age atau masa keemasan dimana pada usia tersebut berada pada perkembangan terbaik untuk fisik dan otak anak. Sesungguhnya tidak hanya pada masa periode emas saja yang penting bagi kehidupan manusia, semua masa adalah penting akan tetapi, pengalamanpengalaman pertama yang biasanya terjadi akan terekam kuat di alam sadar mereka. Pengalaman itulah yang akan menjadi tuntutan seorang anak untuk bersikap dikemudian hari. Hal ini disebabkan karena sirkuit emosi manusia terbentuk sejak bayi hingga usia 6 tahun dan tahap paling kritis ialah usia 4-8 tahun, dimana pada usia ini masa perkembangan yang terangsang mempunyai dampak yang lama pada diri seseorang, pada masa kritis inilah anak masuk dalam usia pra sekolah (Wiyani 2014 :21).

\section{METODE PENELITIAN}

Penelitian ini merupakan penelitian dengan pendekatan kuantitatif. Menurut Sugiyono (2014:8) "Metode penelitian kuantitatif dapat diartikan sebagi metode penelitian yang berlandasan pada filsafat positivisme

Jenis penelitian yang digunakan dalam penelitian ini adalah penelitian survei. Metode penelitian survei dalam penelitian ini menggunakan penelitian komparasi. Penelitian komparasi adalah penelitian yang membandingkan keberadaan satu variabel atau lebih pada dua atau lebih sampel yang berbeda atau pada waktu yang berbeda (Sugiyono, 2014: 36).

\section{HASIL DAN PEMBAHASAN}

Berdasarkan hasil penelitian yang telah dipaparkan diatas dapat diketahui bahwa perhitungan statistik yang telah dilakukan diperoleh data uji-T (Independent Sample t-Test) yaitu $t_{\text {hitung }}>t_{\text {tabel }}(5,085>$ $1,675)$ dan $p_{\text {value }}(0,000<0,05)$. Hal ini dapat dinyatakan bahwasanya terdapat perbedaan yang signifikan terhadap tingkat kemandirian anak usia pra sekolah yang anaknya di asuh oleh ibu yang bekerja dengan kemandirian anak usia pra sekolah yang anaknya di asuh oleh ibu rumah tangga. Analisis deskriptif pada hasil perhitungan yang telah dilakukan telah didapatkan nilai mean 11,17029 untuk anak usia pra sekolah yang diasuh oleh ibu bekerja dan 90,7308 untuk anak usia pra sekolah yang diasuh oleh ibu rumah tangga. Hal ini dapat diartikan bahwa tingkat kemandirian anak usia pra sekolah yang diasuh oleh ibu rumah tangga lebih rendah daripada tingkat kemandirian anak usia pra sekolah yang diasuh oleh ibu bekerja. Pada penelitian yang telah dilakukan, peneliti hanya melihat dari hasil nilai mean saja dikarenakan peneliti hanya melakukan penelitian yang bertujuan untuk melihat perbedaan tingkat kemandirian anak ditinjau dari ibu bekerja dan ibu rumah tangga.

Hasil penelitian ini sesuai dengan teori yang dikemukakan oleh beberapa ahli diantaranya adalah Wiyani ( 2014 : 35 ), ia mengemukakan bahwa faktor-faktor yang mendorong timbulnya kemandirian pada anak di bagi menjadi 2 yaitu faktor internal dan faktor eksternal. Faktor internal meliputi kondisi fisiologis dan kondisi psikologis, sedangkan faktor eksternal meliputi lingkungan, rasa cinta dan kasih sayang orangtua kepada anaknya, pola asuh orangtua dalam keluarga, tingkat kemandirian orangtua, status perkerjaan ibu dan pengalaman anak. Sehingga dapat disimpulkan bahwa status pekerjaan ibu mempengaruhi tingkat kemandirian anak, dimana hal itu berkaitan dengan bagaimana orangtua memberikan perhatian dan kasih sayang kepada anak. Jika seorang ibu bekerja akibatnya si ibu tidak bisa melihat tahap-tahap proses perkembangan anaknya, apakah anaknya sudah bisa mandiri atau belum, sedangkan anak yang ibunya sebagai ibu rumah tangga dapat memperhatikan perkembangan anak, mampu mendidik dan mengawasi anak. Namun kenyataan yang terjadi anak yang ibunya bekerja secara tidak langsung telah menanamkan sifat kemandirian pada anak karena pada saat keberaan ibu tidak bersama anak dalam waktu yang cukup lama, disini anak dituntut untuk memenuhi kebutuhannya sendiri sedangkan anak diasuh oleh ibu rumah tangga lebih kepada keberadaan anak yang selalu berada di sisi ibu dan kemanuan yang anak pinta akan lebih mudah terpenuhi, sehingga menjadikan anak tidak mandiri karena pelayanan yang diberikan ibu tidak 
dikontrol.

\section{KESIMPULAN}

Berdasarkan hasil analisis penelitian tingkat kemandirian anak usia pra sekolah ditinjau dari ibu bekerja dan ibu rumah tangga di Sekolah Alam Jabalussalam Tahun Ajaran 2017/2018, dapat disimpulkan bahwa terdapat perbedaan yang signifikan antara kemandirian anak usia pra sekolah yang diasuh oleh ibu bekerja dengan kemandirian anak usia pra sekolah yang diasuh oleh ibu rumah tangga. Hal ini ditunjukkan dengan perolehan nilai $t_{\text {hitung }}>t_{\text {tabel }}(5,085>1,675)$ dengan taraf nilai signifikansi 0,05 p value $(0,000<0,05)$, maka $H_{o}$ ditolak. Sehingga selanjutnya dapat disimpulkan bahwa status bekerja ibu merupakan salah satu faktor yang dapat mempengaruhi tingkat kemandirian anak usia pra sekolah di Sekolah Alam Jabalussalam.

\section{DAFTAR PUSTAKA}

Al-Qur'an dan Terjemahannya, Departemen Agama RI, Jakarta : Bumi restu, 1976

Alwi, H dkk. (2005). Kamus Besar Bahasa Indonesia. Jakarta: Departemen Pendidikan Nasional Balai Pustaka.

Arikunto, S. (2013). Prosedur Penelitian Suatu Pendekatan Praktik. Jakarta: Rineka Cipta.

Azwar, S. (2014). Metode Penelitian. Yogyakarta: Pustaka Pelajar.

BPS. (2018). Dipetik 05 Thuersday, 2018, dari https://www.bps.go.id/subject/6/tenaga -kerja.html.

Chaplin, J. (2011). Kamus Lengkap Psikologi . Jakarta: Rajawali Pers.

Denrich Suryadi, Cindy Damayanti. (2003). Perbedaan Tingkat Kemandirian Remaja Putri Yang Ibunya Bekerja Dan Yang Tidak Bekerja. Jurnal Psikologi Vol 1, No.1. http://download.portalgaruda.org/articl e.php? article $=62907 \& \mathrm{val}=4564$ diakses pada : 21 April 2018

Depdikbud. (2003). Undang Undang Republik Indonesia Nomor 13 Tahun 2003 tentang Ketenagakerjaan .

Febrimawienda. (2012, 12 Thuersday). Dipetik $05 \quad 15, \quad 2018, \quad$ dari https://febrimawienda.wordpress.com/ 2012/12/11/komponen-komponenkomunikasi-antar-pribadi/

Geofanny, R. (2016). Perbedaan Kemandirian Anak Usia Dini Ditinjau Dari Ibu Bekerja Dan Ibu Tidak Bekerja. PSIKOBORNEO, Vol.4, No.4, 2016, http://ejournal.psikologi.fisipunmul.ac.id/site/wpcontent/uploads/2016/12/JURNAL\%20 RAVIKA\%20GEOFANNY\%20(12-2016-10-43-12).pdf diakses pada : 06 Februari 2018

Hurlock. (1991). Perkembangan Anak. Surabaya: Erlangga.

Idrus, M. (2009). Metode Penelitian Ilmu Sosial Yogyakarta : Erlangga.

Lie, A \& Prasasti, S . (2004). Menjadi Orang Tua Bijak 101 Cara Membina Kemandirian dan Tanggung Jawab Anak. Jakarta: PT Alex Media.

Mariyam, Apisah. (2008). Hubungan Antara Status Pekerjaan Ibu Dan Tingkat Kemandirian Anak Usia Pra Sekolah Di Desa Prapag Lor Kecamatan Losari Kabupaten Brebes . Jurnal Keperawatan Vol2, No 1. https://jurnal.unimus.ac.id/index.php/F IKkeS/article/view/230/239 diakses pada : 26 Juli 2018

Munandar. (1983). Emansipasi Ganda Wanita Indonesia . Jakarta: UI.

Parker, D. (2005). Menumbuhkan Kemandirian dan Harga Diri Anak . Jakarta: PT Prestasi Pustakaraya.

Patmonodewo, D. S. (2008). Pendidikan Anak Prasekolah. Jakarta: Rineka Cipta.

Riwidikdo, H. (2006). Statistik Kesehatan. Yogyakarta: Mitra Cindikia Press

Suardani Luh, dkk. (2016). Perbedaan tingkat kemandirian anak usia 5-6 tahun dilihat dari status pekerjaan ibu dikelurahan banyuning kecamatan buleleng. Jurnal Pendidikan Anak Usia Dini. Vol 4. No 2 https://anzdoc.com/perbedaan-tingkatkemandirian-anak-usia-5-6-tahundilihat-da.html Diakses pada : 6 Februari 2018

Santrock, J. (2007). Psikologi Perkembangan. Edisi 11 Jilid 1. Jakarta: Erlangga. 
Sarwono, J. (2010). Belajar Statistik Menjadi Mudah \& Cepat. Yogyakarta : Andi Oset.

Sugiyono. (2014). Metode Penelitian Kuantitatif Kualitatif Dan R\&D. Bandung : Alfabeta .

Vivi Rukmana, dkk. (2013). Perbedaan kemandirian anak usia 4-5 tahun berasal dari orangtua (ibu) yang bekerja dengan orangtua (ibu) yang tidak bekerja di tk al-hisa hangtuah pekanbaru.

https://repository.unri.ac.id/xmlui/bitstr
eam/handle/123456789/4355/4.Vivi\%2

0Rukmana.pdf?sequence $=1 \&$ isAllowe $\underline{\mathrm{d}=\mathrm{y}}$. Diakses pada : 17 Februari 2018

Wiyani, N. (2014). Bina Karakter Anak Usia Dini: Panduan Orangtua \& Guru Dalam Membentuk Kemandirian \& Kedisiplinan Anak Usia Dini. Yogyakarta : Ar-Ruzz Media.

Yamin, M. \& Sanan, J.S. (2013). Panduan Pendidikan Anak Usia Dini . Jakarta: Gaung Persada Press.

Yulia, A. (2007). Working Mom \& Kids. Jakarta: PT Alex Media Komputindo. 